Check for updates

Cite this: RSC Adv., 2018, 8, 28249

\title{
Sandwich type polyoxometalates encapsulated into the mesoporous material: synthesis, characterization and catalytic application in the selective oxidation of sulfides
}

\begin{abstract}
Elham Naseri and Roushan Khoshnavazi iD *
The A-type sandwich polyoxometalates of $\left[\left(\mathrm{HOSn}^{\mathrm{IV}} \mathrm{OH}\right)_{3}\left(\mathrm{PW}_{9} \mathrm{O}_{34}\right)_{2}\right]^{12-} \quad\left(\mathrm{P}_{2} \mathrm{~W}_{18} \mathrm{Sn}_{3}\right)$ and $\left[\left(\mathrm{OCe}{ }^{\mathrm{IV} O}\right)_{3}\left(\mathrm{PW}_{9} \mathrm{O}_{34}\right)_{2}\right]^{12-}\left(\mathrm{P}_{2} \mathrm{~W}_{18} \mathrm{Ce}_{3}\right)$ were immobilized for the first time into the porous metal-organic framework MIL-101(Cr). FT-IR, powder X-ray diffraction, SEM-EDX, ICP analysis, $\mathrm{N}_{2}$ adsorption and thermogravimetric analysis collectively confirmed immobilization and good distribution of polyoxometalates into cages of MIL-101(Cr). The catalytic activities of the homogeneous $\mathrm{P}_{2} \mathrm{~W}_{18} \mathrm{Sn}_{3}$ and $\mathrm{P}_{2} \mathrm{~W}_{18} \mathrm{Ce}_{3}$ and the corresponding heterogeneous catalysts were examined in the oxidation of sulfides to sulfones with $\mathrm{H}_{2} \mathrm{O}_{2}$ as the oxidant at room temperature. The effects of different dosages of polyoxometalates, type of solvent, reaction time, amount of catalyst and oxidant in this catalytic system were investigated. The new $\mathrm{P}_{2} \mathrm{~W}_{18} \mathrm{Sn}_{3} \mathrm{QMIL}-101$ and $\mathrm{P}_{2} \mathrm{~W}_{18} \mathrm{Ce}_{3} @ \mathrm{aMIL}-101$ nanocomposites exhibited good recyclability and reusability in at least five consecutive reaction cycles without significant loss of activity or selectivity.
\end{abstract}

Received 28th April 2018 Accepted 30th July 2018

DOI: $10.1039 / c 8 r a 03659 d$

rsc.li/rsc-advances

decomposition of guest-free MOFs. ${ }^{\text {16-20 }}$ MIL-101 family of

\section{Introduction}

Polyoxometalates (POMs) as a class of metal cluster complexes comprising transition metal oxide anions attract attention in light of their significant potential in medicine, structural chemistry, analytical chemistry, surface science, electrochemistry and photochemistry. ${ }^{1-3}$ Their utility for catalysis applications has been limited, notably due to their tendency toward low surface area (typically $\leq 10 \mathrm{~m}^{2} \mathrm{~g}^{-1}$ ) and porosity (lower than 0.1 $\mathrm{cm}^{3} \mathrm{~g}^{-1}$ ) of bulk POMs which hinder the accessibility of the active sites, together with a high solubility in polar solvents making it inconvenient for recovery and reutilize. ${ }^{4-6}$ In this sense, the heterogenization or immobilization of POMs onto various solid supports via dative, ${ }^{7}$ covalent, ${ }^{8}$ or electrostatic ${ }^{9-11}$ binding, such as silica, activated carbon, magnetic nanoparticles and titanium dioxide is highly desired to prepare new and robust heterogeneous catalysts, capable of being easily separated from a reaction mixture and recycled..$^{12-14}$ Recently, metal-organic frameworks (MOFs) materials were also used for immobilization of POMs. ${ }^{15}$ Because of their structural features, MOFs relative to other porous matrices play an important role in the development of different catalysts, including those for enantioselective chiral reactions, asymmetric epoxidation of alkenes and allyl alcohols, oxidation of alcohols and in a synthesis of porous carbon materials through thermal

Department of Chemistry, University of Kurdistan, PO. Box 66135-416, Sanandaj, Iran. E-mail: r.khoshnavazi@uok.ac.ir; Fax: +98 87336224133; Tel: +98 87336224133 materials (MIL: Materials of the Institute Lavoisier) are a very stable group of MOFs, result from the three-dimensional covalent connection of inorganic clusters and organic linkers. Its open-pore structure with the pores $(\sim 3.5 \mathrm{~nm})$ and pore windows $(\sim 1.5 \mathrm{~nm})$ are large enough to give access to voluminous reactant molecules diffusing into the pores. These properties and also able to be functionalized, accessible cages and very high specific surface area, make it an excellent candidate to support catalytic species. ${ }^{21-25}$

In 2005, Férey et al. reported incorporation of the lacunary polytungstate of $\mathrm{PW}_{11} \mathrm{O}_{39}{ }^{7-}$ within the large cage of MIL101(Cr). ${ }^{26}$ Following work by Férey et al., numerous POM@MIL101 composite materials containing various catalytically active polyoxometalates has been widely studied, and the resulting composites have been applied to $\mathrm{H}_{2} \mathrm{O}_{2}$-based alkene epoxidation, knoevenagel condensation, aldehyde-alcohol reactions, oxidative desulfurization, aerobic so on. ${ }^{27-30}$ Recently, a range of hybrid materials based on various Keggin polyoxometalates building blocks and copper organic frameworks with pyrazine derivatives have been discussed by Haddadi et al. and used as a heterogeneous catalyst for the selective oxidation of sulfides to corresponding sulfoxides and sulfones using $\mathrm{H}_{2} \mathrm{O}_{2} \cdot{ }^{31}$ A-type sandwich polyoxometalate of $\mathrm{K}_{11} \mathrm{H}\left[\left(\mathrm{HOSn}^{\mathrm{IV}} \mathrm{OH}\right)_{3}\left(\mathrm{PW}_{9} \mathrm{O}_{34}\right)_{2}\right]$. $20 \mathrm{H}_{2} \mathrm{O}$ was immobilized for the first onto Nd-doped $\mathrm{TiO}_{2}$ nanoparticles as support material and these new nanocomposites used for the oxidation of different sulfides and alcohols. ${ }^{32}$ Herein we report the synthesis and application of 


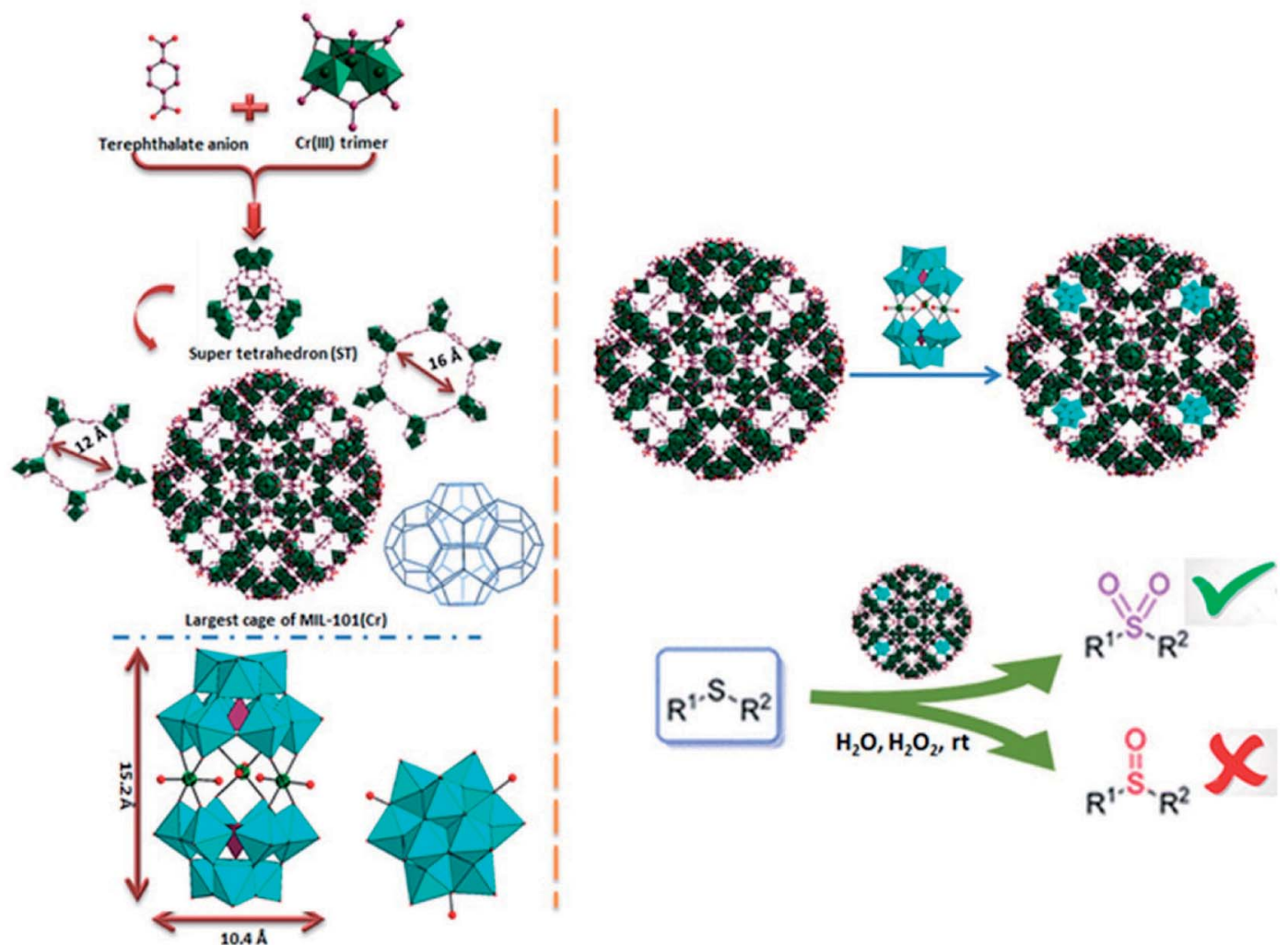

\section{Sandwich type POMs}

Scheme 1 The synthesis pathway for preparation of nanocomposites.

new POM@MIL-101 composites materials containing A-type sandwich polyoxometalates in selective oxidation of sulfides. To the best of our knowledge, this is the first report about the immobilization of various potassium salts of $\left[\left(\mathrm{HOSn}^{\mathrm{IV}} \mathrm{OH}\right)_{3}\left(\mathrm{XW}_{9^{-}}\right.\right.$ $\left.\left.\mathrm{O}_{34}\right)_{2}\right]^{12-}(\mathrm{X}=\mathrm{P}$ and $\mathrm{Si}),\left[(\mathrm{OCe})_{3}\left(\mathrm{XW}_{9} \mathrm{O}_{34}\right)_{2}\right]^{12-}(\mathrm{X}=\mathrm{P})$ and sodium salts $\left[\mathrm{WM}_{3}\left(\mathrm{H}_{2} \mathrm{O}\right)_{2}\left(\mathrm{XW}_{9} \mathrm{O}_{34}\right)_{2}\right]^{12-}(\mathrm{X}=\mathrm{M}=\mathrm{Zn}$ and $\mathrm{Co})$ into a MIL101 metal-organic framework resulting in a series of POM@MOF composite materials in selective oxidation of sulfides. The structure of $\mathrm{P}_{2} \mathrm{~W}_{18} \mathrm{Sn}_{3}$ and $\mathrm{P}_{2} \mathrm{~W}_{18} \mathrm{Ce}_{3}$ consists of two A-type $\mathrm{PW}_{9} \mathrm{O}_{34}$ anions linked by three tin(Iv) or cerium(Iv) cations leading to A-type sandwich POMs (Scheme 1).

\section{Experimental}

\subsection{Materials}

All chemicals were used as received from different commercial sources. All the reagents used in the preparation of the composite materials, namely analytically pure chromium(III) nitrate nonahydrate $\left(\mathrm{Cr}\left(\mathrm{NO}_{3}\right)_{3} \cdot 9 \mathrm{H}_{2} \mathrm{O}\right.$, Aldrich), benzene-1,4dicarboxylic acid $\left(\mathrm{C}_{6} \mathrm{H}_{4}\left(\mathrm{CO}_{2} \mathrm{H}\right)_{2}\right.$, Aldrich), fluorhydric acid (HF, Merck) and DMF (N,N-dimethylformamide, Merck) were purchased and used without further purification. The chemicals used for desulfurization experiments, namely diphenyl sulfide, methyl phenyl sulfide, dimethyl sulfide, 2-(methylthio) ethanol, methyl 3-(methylthio)propionate, 2-furfuryl methyl sulfide, allyl sulfide, dibutyl sulfide (Fluka, 95\%), acetonitrile
$\left(\mathrm{CH}_{3} \mathrm{CN}\right.$, Merck) and hydrogen peroxide $\left(\mathrm{H}_{2} \mathrm{O}_{2}\right.$, Merck 35\%) were also used as received. The A-type sandwich polyoxometalates of $\mathrm{K}_{11} \mathrm{H}\left[\left(\mathrm{HOSn}^{\mathrm{IV}} \mathrm{OH}\right)_{3}\left(\mathrm{PW}_{9} \mathrm{O}_{34}\right)_{2}\right] \cdot 20 \mathrm{H}_{2} \mathrm{O}$ and $\mathrm{K}_{9}\left(\mathrm{NH}_{4}\right) \mathrm{H}_{2}\left[\left(\mathrm{OCe}^{\mathrm{IV}} \mathrm{O}\right)_{3}\left(\mathrm{PW}_{9} \mathrm{O}_{34}\right)_{2}\right] \cdot 20 \mathrm{H}_{2} \mathrm{O}$ were prepared according to the previously described procedures. ${ }^{33,34}$

\subsection{Characterization methods}

The synthesized MOF and nanocomposites were characterized using; Infrared absorption spectra were recorded on a Bruker Vector 22 infrared spectrometer using $\mathrm{KBr}$ pellet method. Thermogravimetric analysis (TGA) was carried out under $\mathrm{N}_{2}$ flow while gradually increasing the temperature with a rate of $10{ }^{\circ} \mathrm{C} \min ^{-1}$, using a STA PT-1000 LINSEIS. The morphology of nanocomposites was revealed by a scanning electron microscope (MIRA3 FEG-SEM). The elements in the nanocomposite samples were probed with energy-dispersive X-ray (EDX) spectroscopy accessory to the MIRA3 FEG-SEM scanning electron microscopy. Nitrogen adsorption-desorption isotherms used to obtain the MIL-101(Cr) and POM@MIL 101(Cr) specific surface areas and pore volumes, calculated by the Brunauer-EmmettTeller (BET) method. All as-prepared samples were degassed at $100{ }^{\circ} \mathrm{C}$ in vacuum for overnight prior to adsorption measurements. The experiments took place at $-196{ }^{\circ} \mathrm{C}$ under variable relative pressure. The equipment was a Belsorp mini II adsorption analyzer (Bel-Japan) at $-196{ }^{\circ} \mathrm{C}$. Powder X-ray diffraction (XRD) analyses were collected at ambient 
temperature by a X'PertPro Panalytical, Holland diffractometer using a CuK $\alpha$ radiation $(\lambda=1.5418 \AA)$. The accelerating voltage and applied currents were $40 \mathrm{kV}$ and $30 \mathrm{~mA}$, respectively. The $\mathrm{C}$ microanalyses was carried out with CHNS-O Elemental Analyzer Vario EL III, ELEMENTARY, Hanau-Germany while the amount of $\mathrm{W}$ and $\mathrm{Cr}$ were measured by inductively coupled plasma mass spectrometry (ICP-MS).

\subsection{Preparation of the materials}

2.3.1. Solid support MIL-101(Cr). The porous metalorganic framework (MOF) material MIL-101(Cr) was prepared hydrothermally, using a modified procedure of the method described by Férey et $a .^{26}$ Benzene-1,4-dicarboxylic acid $\left(\mathrm{H}_{2} \mathrm{BDC}\right)(0.332 \mathrm{~g}, 2 \mathrm{mmol})$ was added in small portions to an aqueous solution of $\mathrm{Cr}\left(\mathrm{NO}_{3}\right)_{3} \cdot 9 \mathrm{H}_{2} \mathrm{O}(0.8 \mathrm{~g}, 2 \mathrm{mmol}$ in $10 \mathrm{~mL}$ of deionized water) and stirred at room temperature to obtain an homogeneous suspension for $20 \mathrm{~min}$, then fluorhydric acid (0.1 $\mathrm{mL}$ ) was added to the above suspension and stirred for $30 \mathrm{~min}$. The dark blue-colored suspension was placed in a Teflon-lined autoclave (125 mL, Paar model 4748), for $9 \mathrm{~h}$ at a heating temperature of $220{ }^{\circ} \mathrm{C}$ without stirring. After slowly cooling to ambient temperature (inside the oven), the green powder was collected by repeated centrifugation and thorough washing with deionized water. Since the product was a mixture of MIL-101 powder and few amounts of needle-like crystals of recrystallized $\mathrm{H}_{2}$ BDC. It was washed overnight with DMF under reflux against the removal of recrystallized $\mathrm{H}_{2}$ BDC. Afterwards, to remove the DMF solvent, the resulting solids were washed with deionized water several times. The product was dried in an air oven at $70{ }^{\circ} \mathrm{C}$ overnight followed by soxhlet extraction in ethanol for $24 \mathrm{~h}$. Samples were activated under vacuum 3 days at $70{ }^{\circ} \mathrm{C}$ with a high yield $83.8 \%$ based on chromium.

2.3.2. $\quad \mathbf{P}_{2} \mathbf{W}_{18} \mathrm{Sn}_{3} @ \mathbf{M I L}-101$ composite. The composite material $\mathrm{P}_{2} \mathrm{~W}_{18} \mathrm{Sn}_{3} @ \mathrm{MIL}-101$ was prepared through the immobilization of the potassium salt of $\mathrm{P}_{2} \mathrm{~W}_{18} \mathrm{Sn}_{3}$ in the porous solid support MIL-101 using a modified procedure of the method described by Balula et al. ${ }^{35}$ In the "impregnation" method, $0.0733 \mathrm{mmol}$ of dry MIL-101 synthesized in an autoclave as described above was added to an aqueous solution of a moderate amount of $\mathrm{P}_{2} \mathrm{~W}_{18} \mathrm{Sn}_{3}(0.25 \mathrm{mM}, 0.5 \mathrm{mM}, 1 \mathrm{mM}$, $2 \mathrm{mM}, 4 \mathrm{mM} ; 15 \mathrm{~mL}$ ) and the mixture was stirred at room temperature for $24 \mathrm{~h}$. The solid separated by centrifugation and then washed several times thoroughly with deionized water and dried in an air oven at $60{ }^{\circ} \mathrm{C}$ overnight followed by activated under vacuum 3 days at $70{ }^{\circ} \mathrm{C}$. Elemental analysis (w/w \%): $\mathrm{C}$, 33.5; Cr, 8.18; W, 21.52. Based on the elemental analysis results and molecular weight of $\mathrm{K}_{11} \mathrm{H}\left[\left(\mathrm{HOSn}^{\mathrm{IV}} \mathrm{OH}\right)_{3}\left(\mathrm{PW}_{9} \mathrm{O}_{34}\right)_{2}\right]$. $20 \mathrm{H}_{2} \mathrm{O}$, W content, 57.98\%; MW, 5708, we estimated the $\mathrm{P}_{2} \mathrm{~W}_{18} \mathrm{Sn}_{3}$ content of the $\mathrm{P}_{2} \mathrm{~W}_{18} \mathrm{Sn}_{3} @ \mathrm{MIL}-101$ materials to be approximately $65 \mu \mathrm{mol} \mathrm{g}{ }^{-1}$ of dry powder, or $37 \mathrm{w} / \mathrm{w} \%$. The content of $\mathrm{P}_{2} \mathrm{~W}_{18} \mathrm{Sn}_{3}$ was calculated according to the formula, $\mu \mathrm{mol} \mathrm{g}^{-1}=1 \times 10^{6}$ (W content in the $\mathrm{P}_{2} \mathrm{~W}_{18} \mathrm{Sn}_{3} @ \mathrm{MIL}-101$, $\%) /\left(\mathrm{MW} \text { of } \mathrm{P}_{2} \mathrm{~W}_{18} \mathrm{Sn}_{3} \times \mathrm{W} \text { content in the } \mathrm{P}_{2} \mathrm{~W}_{18} \mathrm{Sn}_{3} \%\right)^{28}$

2.3.3. $\quad \mathbf{P}_{2} \mathbf{W}_{18} \mathrm{Ce}_{3} @ M I L-101$ composite. The composite material $\mathrm{P}_{2} \mathrm{~W}_{18} \mathrm{Ce}_{3} @ \mathrm{MIL}-101$ was prepared through the immobilization of the potassium salt of $\mathrm{P}_{2} \mathrm{~W}_{18} \mathrm{Ce}_{3}$ in the porous solid support MIL-101 according to the preparation procedure of $\mathrm{P}_{2} \mathrm{~W}_{18} \mathrm{Sn}_{3} @ \mathrm{MIL}-101$ composite unless, $\mathrm{P}_{2} \mathrm{~W}_{18} \mathrm{Sn}_{3}$ was replaced by $\mathrm{P}_{2} \mathrm{~W}_{18} \mathrm{Ce}_{3}$.

\subsection{General test for the oxidation}

A mixture of bulk polyoxometalates $\left(\mathrm{P}_{2} \mathrm{~W}_{18} \mathrm{Sn}_{3}\right.$ or $\left.\mathrm{P}_{2} \mathrm{~W}_{18} \mathrm{Ce}_{3}\right)$ or composites $\left(\mathrm{P}_{2} \mathrm{~W}_{18} \mathrm{Sn}_{3} @ \mathrm{MIL}-101\right.$ or $\left.\mathrm{P}_{2} \mathrm{~W}_{18} \mathrm{Ce}_{3} @ \mathrm{MIL}-101\right)$ (50 $\mathrm{mg}$ ) as catalyst, $35 \% \mathrm{H}_{2} \mathrm{O}_{2}$ aqueous solution (5.85 mmol) and solvent $(2.5 \mathrm{~mL})$ were placed in a $25 \mathrm{~mL}$ glass bottle. After $5 \mathrm{~min}$, the substrate $(1 \mathrm{mmol})$ was added under stirring. The reaction time was counted after the addition of sulfide, and then the reaction mixture was stirred at the experiment temperatures for the appropriate time. The sample was collected from the mixture at time intervals and then the progress of the reaction was followed by TLC (eluent: $n$-hexane/EtOAc, $3: 1$ ) and stopped when a complete conversion of the substrate was observed. The catalyst was filtered off at the end of reactions, washed several times with ethyl acetate followed by ethanol $(4 \times 5 \mathrm{~mL})$, heated in an oven at $70{ }^{\circ} \mathrm{C}$ overnight and then reused using the same reaction conditions. The starting material and product are insoluble in water and it was used just as an environment for stirring. Therefore, the reaction mixture was transferred to a separating funnel and the product was extracted with $\mathrm{CH}_{2} \mathrm{Cl}_{2}$ $(3 \times 5 \mathrm{~mL})$. After evaporation of organic layer, the crude products were recrystallized from hot ethanol and the pure products were obtained in 94-98\% yield. Stability test of the $\mathrm{P}_{2} \mathrm{~W}_{18^{-}}$ $\mathrm{Sn}_{3} @$ MIL-101 and $\mathrm{P}_{2} \mathrm{~W}_{18} \mathrm{Ce}_{3} @$ MIL-101 catalysts were carried out running six consecutive experiments.

\section{Results and discussion}

\subsection{Synthesis}

The MIL-101(Cr) is built up from a corner-sharing of so-called super tetrahedron (hereafter noted ST), which is formed by rigid chromium(III) octahedral trimers (the vertices of the ST) and terephthalate anions (the edges of the ST) (see Scheme 1).

The connection between of the corners of the ST building blocks ensures a 3D cubic zeotype structure with two types of mesoporous cages $(\varnothing=29$ and $34 \AA$ ) (extended MTN topology), accessible through microporous windows $(\varnothing=12$ and $16 \AA)$. The large cages possess both $12 \AA$ pentagonal and $16 \AA$ hexagonal windows with internal free diameters of $34 \AA$. Therefore, these cavities are sufficiently spaced to accommodate large guest molecules (such as the successful encapsulation of the sandwich-type anions, $\mathrm{P}_{2} \mathrm{~W}_{18} \mathrm{Sn}_{3}$ or $\mathrm{P}_{2} \mathrm{~W}_{18} \mathrm{Ce}_{3}(\sim 10.4 \times 10.4 \times$ $\left.15.2 \AA^{3}\right)$ ), into cages of MIL-101(Cr). The MIL-101(Cr) has been employed as a useful and versatile solid support for preparation of heterogeneous catalysts because of its open-pore structure with large and accessible cages. ${ }^{26}$ The incorporation of POMs in the mesoporous MIL-101(Cr) has been carried out by the anionic exchange between the counter-ions of the MIL-101(Cr) (nitrate ions coming from the $\mathrm{Cr}\left(\mathrm{NO}_{3}\right)_{3}$ precursor) and the negatively charged $\mathrm{P}_{2} \mathrm{~W}_{18} \mathrm{Sn}_{3}$ or $\mathrm{P}_{2} \mathrm{~W}_{18} \mathrm{Ce}_{3} \cdot{ }^{36}$ For first time, MIL$101(\mathrm{Cr})$ with $\mathrm{Cr}_{3} \mathrm{~F}\left(\mathrm{H}_{2} \mathrm{O}\right)_{2} \mathrm{O}\left[\left(\mathrm{O}_{2} \mathrm{C}\right)-\mathrm{C}_{6} \mathrm{H}_{4}-\left(\mathrm{CO}_{2}\right)\right]_{3} \cdot n \mathrm{H}_{2} \mathrm{O}$ formula was synthesized by the $\mathrm{HF}-\mathrm{Cr}\left(\mathrm{NO}_{3}\right)_{3}-\mathrm{H}_{2} \mathrm{BDC}-\mathrm{H}_{2} \mathrm{O}$ system. ${ }^{26}$ The composites of the sandwich-type POM of $\mathrm{P}_{2} \mathrm{~W}_{18} \mathrm{Sn}_{3}$ and 
(A)

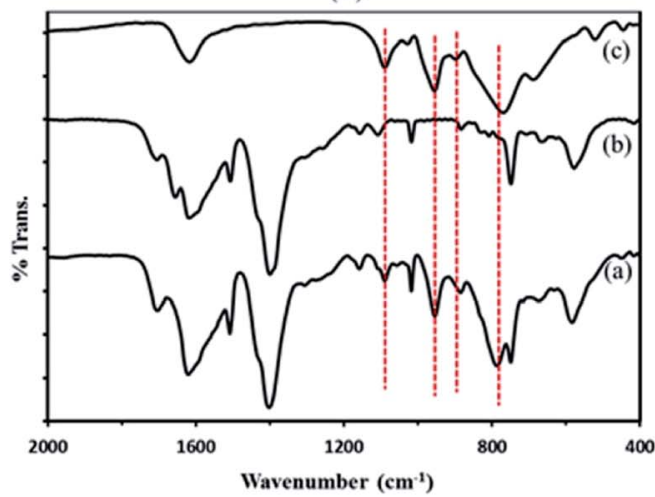

(B)

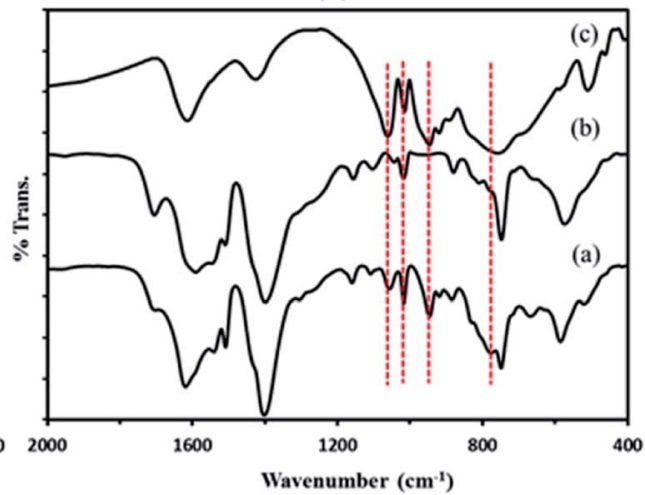

Fig. 1 FT-IR spectra of (A) $P_{2} W_{18} S_{3} @ M I L-101$ composite (a) the precursors of MIL 101 (b) and $P_{2} W_{18} S_{3}$ (c) and (B) $P_{2} W_{18} C e_{3} @ M I L-101$ composite (a) the precursors of MIL 101 (b) and $\mathrm{P}_{2} \mathrm{~W}_{18} \mathrm{Ce}_{3}$ (c).

$\mathrm{P}_{2} \mathrm{~W}_{18} \mathrm{Ce}_{3}$ with MIL-101 were prepared by impregnation of the synthesized MIL-101 in an autoclave as described above in aqueous solution of $\mathrm{P}_{2} \mathrm{~W}_{18} \mathrm{Sn}_{3}$ or $\mathrm{P}_{2} \mathrm{~W}_{18} \mathrm{Ce}_{3}$.

\subsection{Characterization of the material}

3.2.1. FT-IR spectroscopy. The FT-IR spectra of composite materials and those of the precursor compounds of polyoxometalates and the MIL-101 were compared in Fig. 1. The FTIR spectra of composites (Fig. $1 \mathrm{~A}(\mathrm{a})$ and $\mathrm{B}(\mathrm{a})$ ) exhibit the characteristic bands of both the MIL-101 support (Fig. $1 \mathrm{~A}(\mathrm{~b})$ and $\mathrm{B}(\mathrm{b})$ ) and sandwich polyoxometalates $\mathrm{P}_{2} \mathrm{~W}_{18} \mathrm{Sn}_{3}$ or $\mathrm{P}_{2} \mathrm{~W}_{18} \mathrm{Ce}_{3}$ (Fig. 1A(c) and B(c)). The new bands at 1093, 956, 891, $792 \mathrm{~cm}^{-1}$ or 1062, 1018, 948, $784 \mathrm{~cm}^{-1}$ (shown with dashed lines) observed in the spectra of $\mathrm{P}_{2} \mathrm{~W}_{18} \mathrm{Sn}_{3}$ @MIL-101 and $\mathrm{P}_{2} \mathrm{~W}_{18^{-}}$ $\mathrm{Ce}_{3} @$ MIL-101 compared to the that of MIL-101 were attributed to the $\mathrm{P}-\mathrm{O}$ and $\mathrm{W}-\mathrm{O}$ vibrations of the sandwich polyoxometalates $\mathrm{P}_{2} \mathrm{~W}_{18} \mathrm{Sn}_{3}$ (ref. 32) or $\mathrm{P}_{2} \mathrm{~W}_{18} \mathrm{Ce}_{3},{ }^{37}$ respectively. The bands in MIL-101, $\mathrm{P}_{2} \mathrm{~W}_{18} \mathrm{Sn}_{3} @$ @IL-101 and $\mathrm{P}_{2} \mathrm{~W}_{18} \mathrm{Ce}_{3} @ M I L-101$ at $1400 \mathrm{~cm}^{-1}$ and $1552 \mathrm{~cm}^{-1}$ are correspond to $(\mathrm{O}-\mathrm{C}-\mathrm{O}$ ) symmetric vibrations implying the presence of dicarboxylate within the framework, broad and strong bands at around $3430 \mathrm{~cm}^{-1}$ and $1620 \mathrm{~cm}^{-1}$ also confirms the presence of adsorbed water molecules stretching and bending vibrations or the guest molecules inside the pores and the other weak bands in the spectral region of $600-1600 \mathrm{~cm}^{-1}$ are attributed to benzene, including the stretching vibration $\mathrm{C}=\mathrm{C}$ groups $\left(1514 \mathrm{~cm}^{-1}\right)$, in plane and out-of plane bending modes of COO groups (400-700 $\left.\mathrm{cm}^{-1}\right)$, and the out-of plane deformation vibrations of benzene ring $\mathrm{C}-\mathrm{H}$ groups at $1164,1020,889$, and $748 \mathrm{~cm}^{-1} \cdot{ }^{38,39}$

3.2.2. Thermogravimetric analysis (TGA). The TGA curves for the neat MIL-101 (a) and the composites of $\mathrm{P}_{2} \mathrm{~W}_{18} \mathrm{Ce}_{3} @ \mathrm{MIL}$ 101 (b) and $\mathrm{P}_{2} \mathrm{~W}_{18} \mathrm{Sn}_{3} @$ MIL-101 (c) under an inert atmosphere at a constant rate of $10{ }^{\circ} \mathrm{C} \mathrm{min}{ }^{-1}$ are shown in Fig. 2. A thermal gravimetric analysis study on the pristine MIL-101 showed continuous weight loss in the range of $30-800{ }^{\circ} \mathrm{C}$. Two main weight-loss steps were observed below $400{ }^{\circ} \mathrm{C}$ : the first $(5.83 \%)$, relates to the removal of guest water molecules in the small cages, occurs in the range $30-120{ }^{\circ} \mathrm{C}$; a larger loss of $c a .6 .51 \%$ is due to the departure of chemically bonded water and organic solvent (EtOH/DMF) molecules. ${ }^{30}$ The third step occurs in the range $272-800{ }^{\circ} \mathrm{C}$ with loss of about $52.71 \%$ relates to the departure of $\mathrm{OH} / \mathrm{F}$ groups and the decomposition of the framework.

The residual solid is $\mathrm{Cr}_{2} \mathrm{O}_{3}$ for MIL-101. Although, the TGA profile of the composite $\mathrm{P}_{2} \mathrm{~W}_{18} \mathrm{Sn}_{3} @ \mathrm{MIL}-101$ in the first event, occurs in the range $30-310{ }^{\circ} \mathrm{C}(2.27 \%)$, may be assigned to the removal of water molecules present render in the structure electrostatically neutral or the guest molecules inside the pores. A larger loss of $c a .36 .91 \%$ is due to relates to the departure of $\mathrm{OH} / \mathrm{F}$ groups and the decomposition of the framework. The minor weight loss of $2.97 \%$ in the temperature range 600$800{ }^{\circ} \mathrm{C}$ in TGA profile of the composite $\mathrm{P}_{2} \mathrm{~W}_{18} \mathrm{Sn}_{3}$ @MIL-101 can attribute to the loss of oxygen atoms from the residual metal oxides resulted from decomposition of $\mathrm{P}_{2} \mathrm{~W}_{18} \mathrm{Sn}_{3}$. The residual mixture solid is $\mathrm{Cr}_{2} \mathrm{O}_{3}-\mathrm{WO}_{3}-\mathrm{P}_{2} \mathrm{O}_{5}-\mathrm{SnO}_{2}-\mathrm{K}_{2} \mathrm{O}(55.80 \%) .{ }^{40}$ Also, the total weight loss of $42.15 \%$ for $\mathrm{P}_{2} \mathrm{~W}_{18} \mathrm{Sn}_{3} @ \mathrm{MIL}-101$ is lower

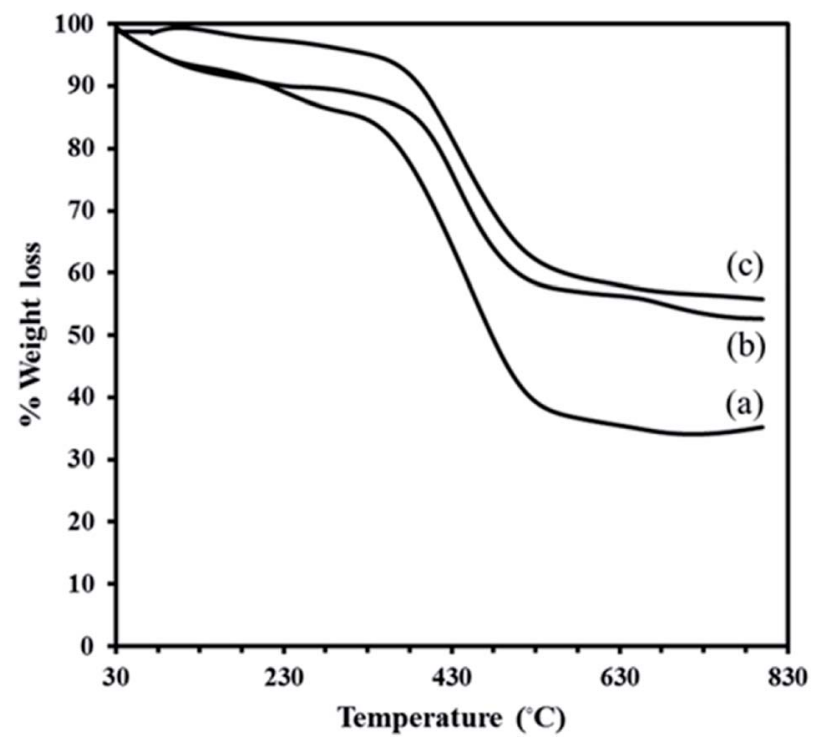

Fig. 2 TGA curves of MIL-101 (a), $P_{2} W_{18} C_{3} @ M I L-101(b)$ and $P_{2} W_{18^{-}}$ $\mathrm{Sn}_{3} \mathrm{QMIL-101}$ (c). 

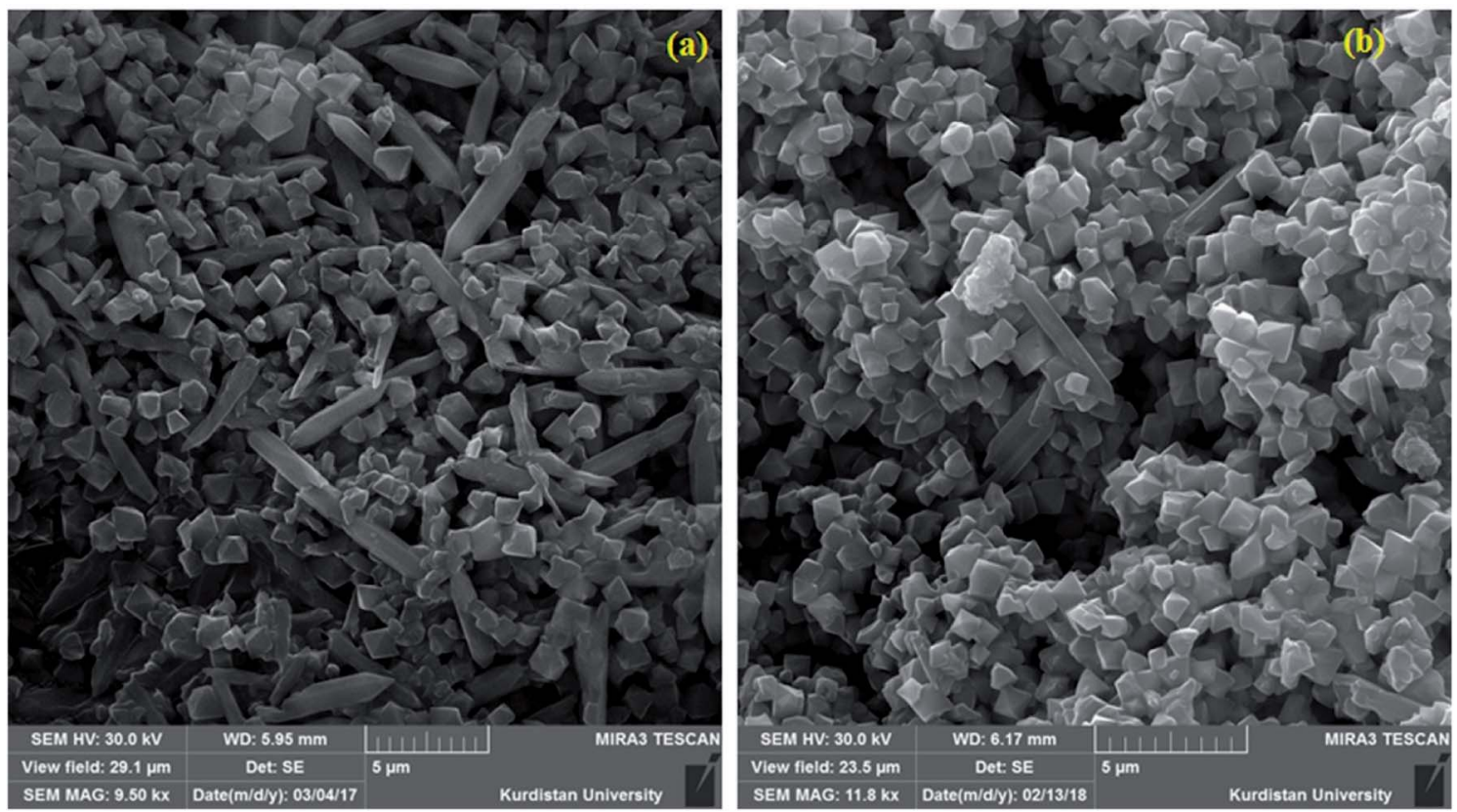

Fig. 3 SEM images of MIL-101 (a) and $\mathrm{P}_{2} \mathrm{~W}_{18} \mathrm{Ce}_{3} \mathrm{QMIL-101}$ (b).

than that for the parent MIL-101 (65.05\%), as would be expected from the presence additional residual from partial decomposition of $\mathrm{P}_{2} \mathrm{~W}_{18} \mathrm{Sn}_{3}$ in the cages of composite. The TGA curve of the $\mathrm{P}_{2} \mathrm{~W}_{18} \mathrm{Ce}_{3} @ \mathrm{MIL}-101$ composite shows a two-stage weight loss below $600{ }^{\circ} \mathrm{C}$, such as the $\mathrm{P}_{2} \mathrm{~W}_{18} \mathrm{Sn}_{3} @ \mathrm{MIL}-101$ composite, and indicates a lower weight loss than MIL-101. From TGA curves can be recognized that polyoxotungstate anions improve the thermal stability of the neat MIL-101. ${ }^{41}$

3.2.3. SEM and EDX. The SEM image of the MIL-101 was displayed frequently octahedral with some hexagonal MOF rods (Fig. 3a). As depicted in Fig. 3b, the SEM image the $\mathrm{P}_{2} \mathrm{~W}_{18^{-}}$ $\mathrm{Ce}_{3} @$ MIL-101 composite material appears like an aggregation state of nano crystallites with the similar morphology of the solid support MIL-101, pointing to the preservation of structure the solid support after the incorporation of $\mathrm{P}_{2} \mathrm{~W}_{18} \mathrm{Ce}$. EDX analyses of MIL-101 and nanocomposites materials of $\mathrm{P}_{2} \mathrm{~W}_{18^{-}}$ $\mathrm{Sn}_{3} @ M I L-101$ and $\mathrm{P}_{2} \mathrm{~W}_{18} \mathrm{Ce}_{3} @$ @IL-101 demonstrate that all of the elements of MIL-101 and the polyoxometalate anions in the samples which it confirms the presence of the polyoxotungstate anions in POMs@MIL-101 (Fig. 4).
3.2.4. $\mathbf{N}_{2}$ adsorption. Chromium terephthalates contained significant amounts of free guest molecules (solvent or other chemicals used during the synthesis for example; terephthalic acid or DMF) within the pores. To evacuate the free molecules from the MOF with compromising its structural integrity and hence porosity, two effective activation steps were performed. The exchange of the high-boiling point solvent, (e.g., DMF), used for purification, by a lower boiling point solvent (e.g., EtOH) followed by simple heat and vacuum treatment. ${ }^{42}$ DMF molecules were completely removed from the MIL-101 after solvent exchange for one day and activation at $70{ }^{\circ} \mathrm{C}$ for 3 days under vacuum. After post-treatment, the pore textural properties enhanced for the as-synthesized MIL-101. Nitrogen adsorption isotherms for $\mathrm{P}_{2} \mathrm{~W}_{18} \mathrm{Sn}_{3}$, MIL-101 (activated with ethanol), $\mathrm{P}_{2}$ $\mathrm{W}_{18} \mathrm{Sn}_{3} @ \mathrm{MIL}-101$ and $\mathrm{P}_{2} \mathrm{~W}_{18} \mathrm{Ce}_{3} @ \mathrm{MIL}-101$ are shown in Fig. 5 at boiling temperature $(77 \mathrm{~K})$ after evacuating guest molecules from the samples at $100{ }^{\circ} \mathrm{C}$ for overnight. As noted above, the major disadvantages of POMs as catalyst are low surface areas as well as POMs in the bulk phase display no characteristic porosity which limit their utility in many catalytic reactions.



Fig. 4 EDX spectra of (a) MIL-101 and the composite of $\mathrm{P}_{2} \mathrm{~W}_{18} \mathrm{Sn}_{3} @ \mathrm{QMIL}-101$ (b) and $\mathrm{P}_{2} \mathrm{~W}_{18} \mathrm{Ce} \mathrm{e}_{3} \mathrm{QMIL}-101$ (c). 
A

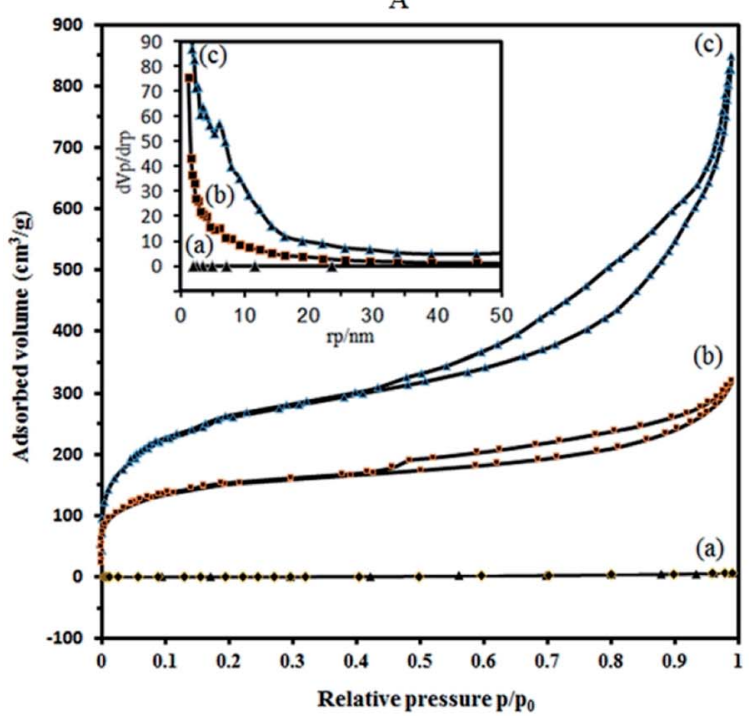

B

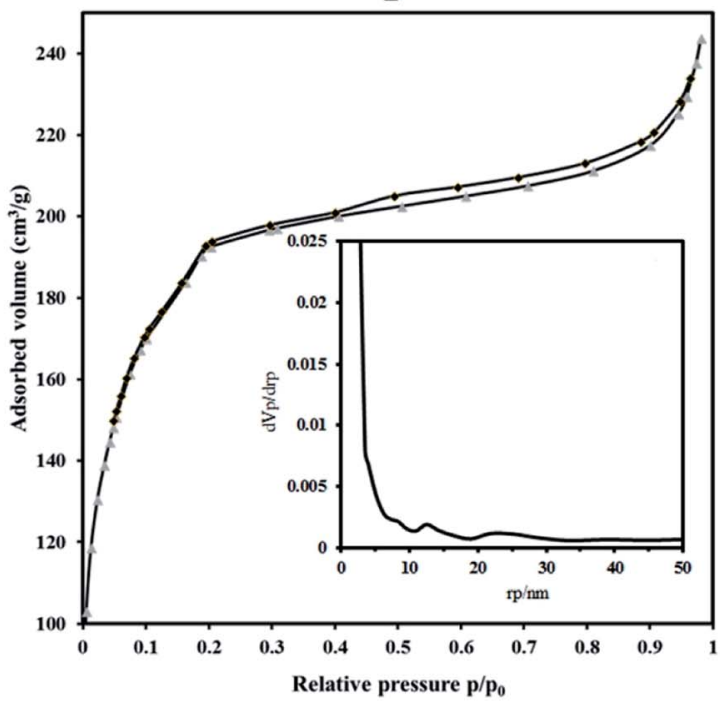

Fig. $5 \mathrm{~N}_{2}$ adsorption-desorption isotherms at $77 \mathrm{~K}$ of (A) $\mathrm{P}_{2} \mathrm{~W}_{18} \mathrm{Sn}_{3}$ (a), the composite $\mathrm{P}_{2} \mathrm{~W}_{18} \mathrm{Sn}_{3} \mathrm{QMIL} 101$ (b) and MIL 101 (c). (B) The composite $\mathrm{P}_{2} \mathrm{~W}_{18} \mathrm{Ce}_{3} \mathrm{QMIL}$ 101. Inset shows BJH pore-size distribution plots of the samples.

To overcome these problems, it is proposed that increasing the surface area can be achieved by the deposition of sandwich POM into porous solid supports with high surface area. The results of the BET analysis show that the specific surface area of $\mathrm{P}_{2} \mathrm{~W}_{18} \mathrm{Sn}_{3}$ is much lower compared to composite (Fig. $5 \mathrm{~A}(\mathrm{a})$ ).

Nitrogen adsorption isotherms show that the specific surface area of the dehydrated MIL-101 decrease from $946.91 \mathrm{~m}^{2} \mathrm{~g}^{-1}$ to $573.08 \mathrm{~m}^{2} \mathrm{~g}^{-1}$ for $\mathrm{P}_{2} \mathrm{~W}_{18} \mathrm{Sn}_{3} @ M I L-101$. Importantly, compared with MIL-101, $\mathrm{P}_{2} \mathrm{~W}_{18} \mathrm{Sn}_{3} @ M I L-101$ shows a smaller pore volume (1.312 $\mathrm{cm}^{3} \mathrm{~g}^{-1}$ to $0.491 \mathrm{~cm}^{3} \mathrm{~g}^{-1}$ ), which may help to interpret the lower specific surface area for composite. Combined with $\mathrm{N}_{2}$ sorption isotherms analysis and the pore size distribution (PSD) results, it can be concluded that the doping of the MIL-101 porous structure with POM ions can change morphological characteristics (surface area, pore volume and pore size distributions). ${ }^{43,44}$

Adsorption isotherms of $\mathrm{P}_{2} \mathrm{~W}_{18} \mathrm{Sn}_{3} @ \mathrm{MIL}-101$ (Fig. 5A(b)), as well as MIL-101 (Fig. 5A(c)), reveal typical type-I behavior with remarkable $\mathrm{H}_{4}$ hysteresis loop which is coincident with the mesoporous structures. This hysteresis is usually characteristic of solids consisting of aggregates of particles forming slitshaped pores (plates or edged particles like cubes), with uniform or non-uniform size and/or shape. These results are in good agreement with the results of the pore size distribution (calculated by $\mathrm{BJH}$ method based on the adsorption branch) of $\mathrm{P}_{2} \mathrm{~W}_{18} \mathrm{Sn}_{3}$, the MIL-101 and $\mathrm{P}_{2} \mathrm{~W}_{18} \mathrm{Sn}_{3} @$ MIL-101 materials. From the distribution curves, the samples have a broad poresize distribution in the range of 1.2-30 nm (Fig. 5 inset).

The $\mathrm{N}_{2}$ adsorption isotherm and the $\mathrm{BJH}$ pore size distribution curve of $\mathrm{P}_{2} \mathrm{~W}_{18} \mathrm{Ce}_{3} @ M I L-101$ catalyst shown in Fig. 5B. Importantly, compared with the MIL-101, $\mathrm{P}_{2} \mathrm{~W}_{18} \mathrm{Ce}_{3} @ \mathrm{MIL}-101$ catalyst shows the surface area and total pore volume is reduced to $690.14 \mathrm{~m}^{2} \mathrm{~g}^{-1}$ and $0.376 \mathrm{~cm}^{3} \mathrm{~g}^{-1}$, in agreement with the presence of heavy polyoxometalate moieties. According to the results of the Barrett-Joyner-Halenda (BJH) analysis, mesoporous structure are present in both nanocomposites, especially in $\mathrm{P}_{2} \mathrm{~W}_{18} \mathrm{Sn}_{3} @ \mathrm{MIL}-101$ catalyst, in agreement with its hysteresis loop at relative pressure $\left(P / P_{0}\right)$ between 0.4 and $1.0 .^{45}$ The results of the $\mathrm{N}_{2}$ adsorption-desorption isotherms and pore size distributions of the synthesized nanocomposites show that the type of polyoxometalate loaded in the cavities of the MIL-101 affects the volume and size distribution of the pores in the material.

3.2.5. Powder X-ray diffraction. Fig. 6 shows the XRD patterns of MIL-101, $\mathrm{P}_{2} \mathrm{~W}_{18} \mathrm{Sn}_{3} @ M I L-101, \mathrm{P}_{2} \mathrm{~W}_{18} \mathrm{Ce}_{3} @ M I L-101$ and sandwich polyoxometalates $\mathrm{P}_{2} \mathrm{~W}_{18} \mathrm{M}_{3}(\mathrm{M}=\mathrm{Sn}$ and $\mathrm{Ce})$ in the $2 \theta$ range of $5-50^{\circ}$. XRD patterns of the obtained MIL-101 metal-organic framework was analyzed referring to the simulated XRD patterns of the MIL-101 single crystal. The simulated XRD patterns of MIL-101 (Fig. 6) exhibited five strong peaks at

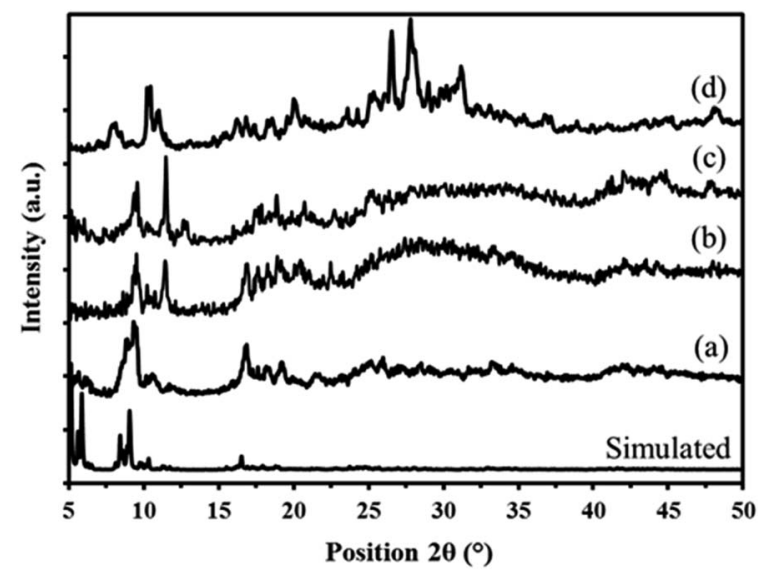

Fig. 6 Powder $\mathrm{X}$-ray diffraction patterns of simulated and prepared MIL-101 (a) $\mathrm{P}_{2} \mathrm{~W}_{18} \mathrm{Sn}_{3} \mathrm{QMIL-101}$ (b) and $\mathrm{P}_{2} \mathrm{~W}_{18} \mathrm{Ce}_{3} \mathrm{QMIL-101}$ (c) sandwich polyoxometalates $\mathrm{P}_{2} \mathrm{~W}_{18} \mathrm{M}_{3}(\mathrm{~d})$. 
$2 \theta=5.2^{\circ}, 5.6^{\circ}, 5.9^{\circ}, 8.4^{\circ}, 9.1^{\circ}$ corresponding to the 511,440 , 351,822 , 911 reflection, respectively. ${ }^{46,47}$ As seen in Fig. 6a, the all of the diffraction peaks corresponding to the obtained MIL101 are in good agreement with the standard sample. It can see the diffraction peaks of the $\mathrm{P}_{2} \mathrm{~W}_{18} \mathrm{Sn}_{3}$ @MIL-101 (Fig. 6b) include both characteristic peaks of MIL-101 and $\mathrm{P}_{2} \mathrm{~W}_{18} \mathrm{Sn}_{3}$ polyoxotungstate (Fig. 6d), revealing the existence of $\mathrm{P}_{2} \mathrm{~W}_{18} \mathrm{Sn}_{3}$ and their basically intact the crystalline characters of the parent metal-organic framework. Powder X-ray diffraction pattern of $\mathrm{P}_{2} \mathrm{~W}_{18} \mathrm{Sn}_{3} @ \mathrm{MIL}-101$ shows a less-ordered structures pattern which implying that the occupation of pore channels of MIL-101 by polyoxometalate and change in electronic environment around $\mathrm{Cr}$ atoms (Fig. 6b). ${ }^{48}$

The X-ray diffraction pattern of the $\mathrm{P}_{2} \mathrm{~W}_{18} \mathrm{Ce}_{3} @ \mathrm{MIL}-101$ nanocomposite is in good agreement with $\mathrm{P}_{2} \mathrm{~W}_{18} \mathrm{Sn}_{3} @ \mathrm{MIL}$ 101, thus confirming both polyoxotungstates have the same diffraction pattern (Fig. 6c).

\subsection{Catalytic activity}

Organosulfur compounds, such as sulfoxides and sulfones, are useful synthetic intermediates for the construction of various pharmaceutically and biologically active compounds. They are widely utilized as anti-bacterial, anti-fungal, antiatherosclerotic, anti-ulcer, vasodilators and cardiotonic agents and as well as activation of enzymes. Different synthetic methods for the controlled oxidation of conventional sulfides have been previously reported for fundamental transformation. Traditionally, these transformations take place with stoichiometric amounts of electrophilic reagents, such as peracids, dioxiranes, hypochlorites, periodates and highly toxic oxo metal oxidants $\left(\mathrm{NaIO}_{4}, \mathrm{MnO}_{2}, \mathrm{CrO}_{3}, \mathrm{SeO}_{2}, \mathrm{PhIO}, \mathrm{NH}_{4} \mathrm{MnO}_{4}\right.$ and so on) but, many of these procedures are accompanied by particular disadvantages such as toxic and corrosive oxidants, long reaction times, inconvenient reaction conditions, environmentally unfavorable catalysts (poor recovery of expensive metal catalysts), low yields and the formation of toxic wastes. ${ }^{\mathbf{4 9 , 5 0}}$ Various catalyst systems of organocatalysts, acid catalysts, enzymes, metal catalysts and organic-inorganic hybrid solid materials have been used for this reaction with $\mathrm{H}_{2} \mathrm{O}_{2}$ as an oxygen source. Recently, the use of polyoxometalates was promising not only due to bifunctional redox acid catalysts properties but also due to their unusual properties such as high charges, low cost and low environmental impact. ${ }^{51-53}$

The reaction initially performed in the presence of $5.85 \mathrm{mmol}$ of $\mathrm{H}_{2} \mathrm{O}_{2}$ as an oxidant, employing $1 \mathrm{mmol}(0.17 \mathrm{~mL})$ diphenyl sulfide and $50 \mathrm{mg}$ of catalyst in $\mathrm{CH}_{3} \mathrm{CN}(2.5 \mathrm{~mL})$ at room temperature. In order to find the optimum reaction conditions, the effect of different reaction parameters such as the amount of catalyst, the stoichiometry of $\mathrm{H}_{2} \mathrm{O}_{2}$ respect to the catalyst and substrate, solvent, reaction time, different dosages of POM into MIL-101 and the catalytic activities of the different catalysts on the selectivity and conversion of the oxidation reaction were studied. No product was obtained in the absence of any catalyst (Table 1, entry 1). At first, the catalytic performance was evaluated for the selective oxidation of sulfides using MIL-101 support and the POMs $\left(\mathrm{P}_{2} \mathrm{~W}_{18} \mathrm{Sn}_{3}\right.$ and $\left.\mathrm{P}_{2} \mathrm{~W}_{18} \mathrm{Ce}_{3}\right)$ as homogeneous catalysts in different reaction conditions (Table 1, entries 2-6).

The $\mathrm{P}_{2} \mathrm{~W}_{18} \mathrm{Sn}_{3}$ as a homogeneous catalyst in the presence of hydrogen peroxide in $\mathrm{H}_{2} \mathrm{O}$ or $\mathrm{CH}_{3} \mathrm{CN}$ as solvent unsuitable conversion and selectivity was found even in prolonged reaction time (Table 1 entries 3 and 4). The $\mathrm{P}_{2} \mathrm{~W}_{18} \mathrm{Ce}_{3}$ as a homogeneous catalyst in the presence of hydrogen peroxide, although in $\mathrm{H}_{2} \mathrm{O}$ do not show suitable activity but, it catalyzes selectively the oxidation of sulfides to sulfone in about $180 \mathrm{~min}$ in EtOH (Table 1 entries 5 and 6). Although the conversion and the selectivity of

Table 1 Optimization of the reaction conditions with respect to the effect of the different catalysts ${ }^{c}$ and solvent on the oxidation of diphenyl sulfide

\begin{tabular}{|c|c|c|c|c|c|}
\hline Entry & Catalyst (mg) & Solvent & Time (min) & Sulfoxide $(\%)^{a}$ & Sulfone $(\%)^{a}$ \\
\hline $1^{b}$ & Catalyst free & $\mathrm{CH}_{3} \mathrm{CN}$ & 1440 & Trace & - \\
\hline 2 & MIL-101 (50) & $\mathrm{CH}_{3} \mathrm{CN}$ & 1440 & 40 & 20 \\
\hline 4 & $\mathrm{P}_{2} \mathrm{~W}_{18} \mathrm{Sn}_{3}(50)$ & $\mathrm{H}_{2} \mathrm{O}$ & 1440 & Trace & Trace \\
\hline 5 & $\mathrm{P}_{2} \mathrm{~W}_{18} \mathrm{Ce}_{3}(50)$ & $\mathrm{H}_{2} \mathrm{O}$ & 1440 & Trace & Trace \\
\hline 6 & $\mathrm{P}_{2} \mathrm{~W}_{18} \mathrm{Ce}_{3}(50)$ & EtOH & 180 & - & 98 \\
\hline 9 & Catalyst (3) (50) & $\mathrm{CH}_{3} \mathrm{CN}$ & 210 & - & 98 \\
\hline 10 & Catalyst (4) (50) & $\mathrm{CH}_{3} \mathrm{CN}$ & 260 & - & 98 \\
\hline 11 & Catalyst (5) (50) & $\mathrm{CH}_{3} \mathrm{CN}$ & 320 & - & 98 \\
\hline 12 & Catalyst (1) (50) & $\mathrm{H}_{2} \mathrm{O}$ & 210 & - & 98 \\
\hline 13 & Catalyst (1) (50) & EtOH & 220 & - & 98 \\
\hline 14 & Catalyst (1) (50) & $\mathrm{H}_{2} \mathrm{O} / \mathrm{PEG}$ & 220 & - & 98 \\
\hline
\end{tabular}

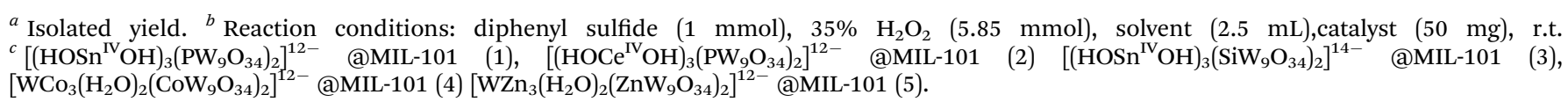


$\mathrm{P}_{2} \mathrm{~W}_{18} \mathrm{Ce}_{3}$ in EtOH were good, but there are two problems about its separation and recovery. We found that like some of POMs, the structure of $\mathrm{P}_{2} \mathrm{~W}_{18} \mathrm{Ce}_{3}$ in the presence of hydrogen peroxide was converted to a mixture of peroxopolytungstophosphate species. ${ }^{\mathbf{5 4 5 5}}$ As shown in Table 1, the oxidation of substrate was carried out using the heterogeneous catalysts. Catalytic oxidation of sulfides was carried out in the presence of the MIL-101 composites of various sandwich-type polyoxometalates.

Within this context, $\left[\left(\mathrm{HOSn}^{\mathrm{IV}} \mathrm{OH}\right)_{3}\left(\mathrm{PW}_{9} \mathrm{O}_{34}\right)_{2}\right]^{12-}$ @MIL101, $\left[\left(\mathrm{OCe}^{\mathrm{IV}} \mathrm{O}\right)_{3}\left(\mathrm{PW}_{9} \mathrm{O}_{34}\right)_{2}\right]^{12-} @ \mathrm{MIL}-101, \quad\left[\left(\mathrm{HOSn}^{\mathrm{IV}} \mathrm{OH}\right)_{3}(-\right.$ $\left.\left.\mathrm{SiW}_{9} \mathrm{O}_{34}\right)_{2}\right]^{14-} @ M I L-101,\left[\mathrm{WCo}_{3}\left(\mathrm{H}_{2} \mathrm{O}\right)_{2}\left(\mathrm{CoW}_{9} \mathrm{O}_{34}\right)_{2}\right]^{12-} @ M I L-$ 101 and $\left[\mathrm{WZn}_{3}\left(\mathrm{H}_{2} \mathrm{O}\right)_{2}\left(\mathrm{ZnW}_{9} \mathrm{O}_{34}\right)_{2}\right]^{12-}$ @MIL-101 composites were prepared and their catalytic activities investigated for the oxidation of diphenyl sulfide by using $\mathrm{H}_{2} \mathrm{O}_{2}$ as an oxidant at room temperature in $\mathrm{CH}_{3} \mathrm{CN}$ (Table 1, entries 7-11). The results in Table 1 clearly show that $\mathrm{P}_{2} \mathrm{~W}_{18} \mathrm{Sn}_{3} @ \mathrm{MIL}-101$ and $\mathrm{P}_{2} \mathrm{~W}_{18} \mathrm{Ce}_{3}$ @MIL-101 showed the highest selectivity for oxidizing of diphenyl sulfide in short reaction time with $98 \%$ yield of the corresponding sulfone. Increasing catalysts over $50 \mathrm{mg}$ and also $\mathrm{H}_{2} \mathrm{O}_{2}$ more over than $1 \mathrm{~mL}$ doesn't have an appreciable effect on the reaction times. The role of different solvents for the oxidation of diphenyl sulfide was examined. As shown in Table 1 ; in presence $\mathrm{P}_{2} \mathrm{~W}_{18} \mathrm{Sn}_{3}$ @MIL-101 when we used acetonitrile as solvent, the desired product (sulfone) can be obtained in a shorter time (Table 1, entry 7). By using $\mathrm{H}_{2} \mathrm{O}$, EtOH or $\mathrm{H}_{2} \mathrm{O} / \mathrm{PEG}$ as solvent similar catalytic conversion and selectivity obtained but at prolonged reaction time (Table 1, entries 12-14). DMF as solvent, the mixture of

Table 2 Selective oxidation of various sulfides to sulfones using $\mathrm{H}_{2} \mathrm{O}_{2}$ catalyzed by $\mathrm{P}_{2} \mathrm{~W}_{18} \mathrm{Sn}$ (aMIL-101

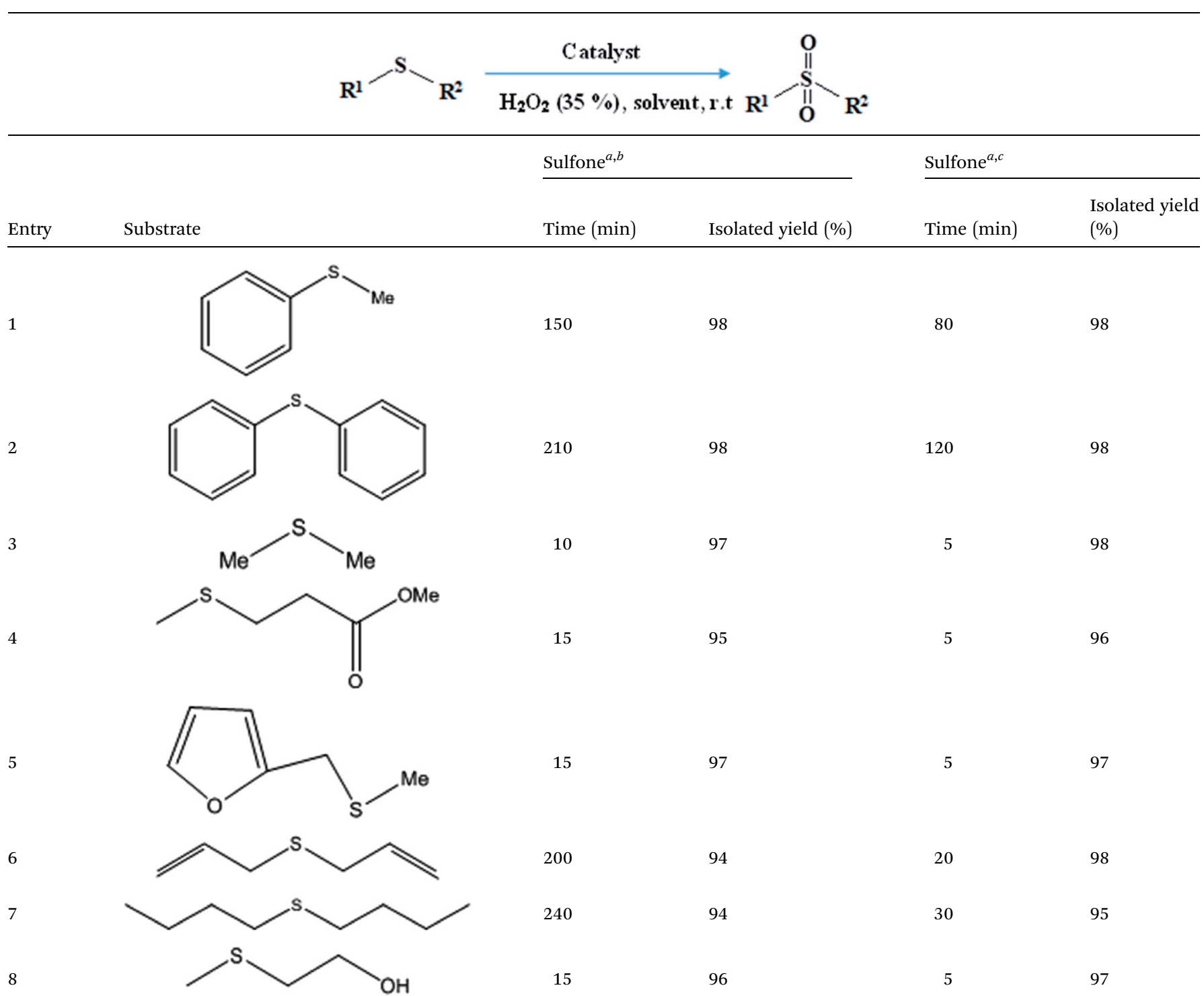

${ }^{a}$ All the products are known and were characterized by FT-IR and by melting point comparison with those of authentic samples. ${ }^{b}$ Reaction conditions: sulfide $(1 \mathrm{mmol}), 35 \% \mathrm{H}_{2} \mathrm{O}_{2}(5.85 \mathrm{mmol})$, catalyst $(50 \mathrm{mg})$, in $\mathrm{H}_{2} \mathrm{O}$, r.t. ${ }^{c}$ Reaction conditions: sulfide $(1 \mathrm{mmol}), 35 \% \mathrm{H}_{2} \mathrm{O}_{2}(5.85$ $\mathrm{mmol}$ ), catalyst (50 $\mathrm{mg})$, in $\mathrm{CH}_{3} \mathrm{CN}$, r.t. 




Fig. 7 The reusability of $\mathrm{P}_{2} \mathrm{~W}_{18} \mathrm{Sn}_{3} \mathrm{QMIL}-101$ (gray) and $\mathrm{P}_{2} \mathrm{~W}_{18} \mathrm{Ce}_{3} \mathrm{a}-$ MIL-101 (orange) catalysts in the oxidation of sulfides. sulfoxide and sulfone is obtained (Table 1, entry 15). Generally, the solvent type is chosen based on the reaction kinetic and catalyst structure, so choosing the suitable solvents according to the chemical structure, molecular design and its physical and chemical properties is very important in reaction systems. With regard to the porous catalyst in our study, it was not possible to use solvent-free conditions because reactants have to interact with catalytic active species located in the cavities. It is necessary to mention, the reaction in acetonitrile showed a good reactivity (excellent conversion and selectivity), in our this work. On the other hand, in protic solvents such as water, it is possible that Lewis acid sites $\left(\mathrm{Cr}^{\mathrm{III}}\right)$ in the structure of the nanocomposite interact with protons of solvent and thus the cavities are blocked, so it is difficult to insertion-extraction for reactants.

The influence of temperature in the diphenyl sulfide oxidation is illustrated with keeping $\mathrm{H}_{2} \mathrm{O}_{2}$ and substrate

Table 3 Selective oxidation of various sulfides to sulfones using $\mathrm{H}_{2} \mathrm{O}_{2}$ catalyzed by $\mathrm{P}_{2} \mathrm{~W}_{18} \mathrm{Ce}_{3} \mathrm{QMIL}-101$

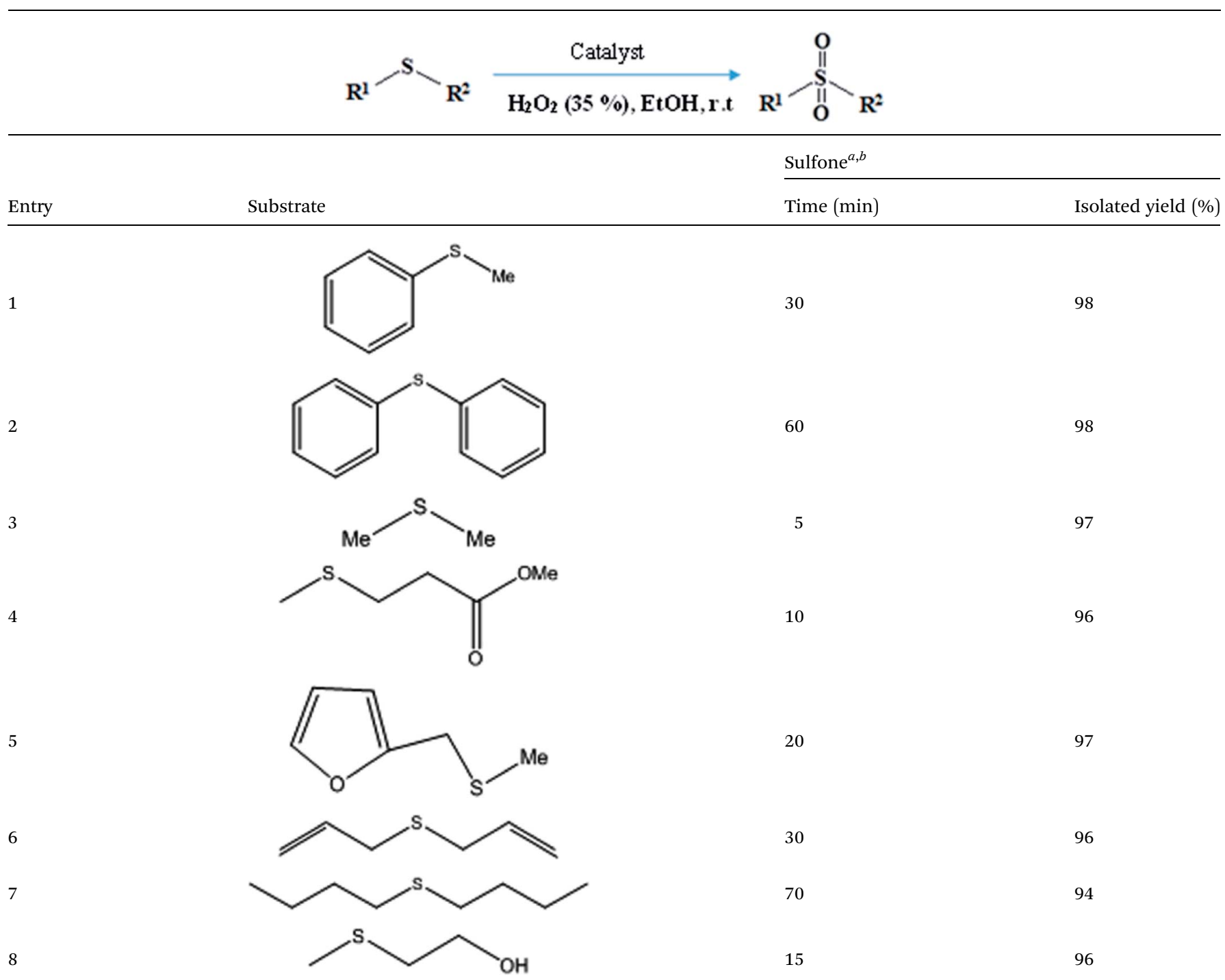

${ }^{a}$ All the products are known and were characterized by FT-IR and by melting point comparison with those of authentic samples. ${ }^{b}$ Reaction conditions: sulfide $(1 \mathrm{mmol}), 35 \% \mathrm{H}_{2} \mathrm{O}_{2}(5.85 \mathrm{mmol})$, catalyst $(50 \mathrm{mg})$, in EtOH, r.t. 



Fig. 8 The FT-IR spectra of (A) $\mathrm{P}_{2} \mathrm{~W}_{18} \mathrm{Sn}_{3} \mathrm{QMIL}-101$ composite (a) and $\mathrm{P}_{2} \mathrm{~W}_{18} \mathrm{Sn}_{3} \mathrm{QMIL}-101$ after six consecutive runs (b) and (B) $\mathrm{P}_{2} \mathrm{~W}_{18} \mathrm{Ce} \mathrm{e}_{3} \mathrm{QMIL}-$ 101 composite (a) and $\mathrm{P}_{2} \mathrm{~W}_{18} \mathrm{Ce}_{3} @ \mathrm{M} \mathrm{MIL}-101$ after six consecutive runs (b).

amount constant. We found similar results at 25 to $50{ }^{\circ} \mathrm{C}$. The reaction was completed selectively in $60^{\circ} \mathrm{C}$ at shorter reaction time. Increasing temperature to $85{ }^{\circ} \mathrm{C}$ conversion was completed while the selectivity decreased. $\mathrm{P}_{2} \mathrm{~W}_{18} \mathrm{Ce}_{3} @ \mathrm{MIL}-101$ the best catalytic activity observed in $\mathrm{CH}_{3} \mathrm{CN}$ and EtOH as solvent (Table 1, entries 8 and 16), while in $\mathrm{H}_{2} \mathrm{O}$ the same catalytic activity observed only at very prolonged time (Table 1 , entry 17$)$.

The used polyoxometalates have similar structure and the difference among them is the metal ions in the belt of the used sandwich type polyoxometalates. Therefore, the difference in their catalytic activity can be attributed to type of metal ions. The nanocomposites of $\mathrm{P}_{2} \mathrm{~W}_{18} \mathrm{Sn}_{3} @ \mathrm{MIL}-101$ and $\mathrm{P}_{2} \mathrm{~W}_{18} \mathrm{Ce}_{3} @$ MIL-101 show the best catalytic activity which it can be attributed to the $\mathrm{Sn}^{\mathrm{IV}}$ or $\mathrm{Ce}^{\mathrm{IV}}$ ions in their structures. A comparison between the latters, show that the best results obtained with $\mathrm{P}_{2} \mathrm{~W}_{18} \mathrm{Ce}_{3} @ \mathrm{MIL}-101$. Two aligned reasons can be proposed for preference of $\mathrm{P}_{2} \mathrm{~W}_{18} \mathrm{Ce}_{3} @ \mathrm{MIL}-101$ composite. First, particular ability of cerium in store/release oxygen as an oxygen storage via facile reciprocal transformation of $\mathrm{Ce}^{\mathrm{IV}}$ and $\mathrm{Ce}^{\mathrm{III}}$ ions under oxidizing and reducing conditions respectively. Due to this feature, activated oxygen species produced from $\mathrm{H}_{2} \mathrm{O}_{2}$, may be stored on the composite, which in turn, may be responsible for oxidation of sulfide. ${ }^{56-58}$ Second, standard electrode potential for reduction of $\mathrm{Ce}^{\mathrm{IV}}$ to $\mathrm{Ce}^{\mathrm{III}}$ in the $\mathrm{P}_{2} \mathrm{~W}_{18} \mathrm{Ce}_{3} @ M I L-101$ is very more positive than that $\mathrm{Sn}^{\mathrm{IV}}$ to $\mathrm{Sn}^{\mathrm{II}}$ in the $\mathrm{P}_{2} \mathrm{~W}_{18} \mathrm{Sn}_{3} @ \mathrm{MIL}-101$. As an interesting result, in contrast to homogenous condition, the $\mathrm{P}_{2} \mathrm{~W}_{18} \mathrm{Ce}_{3}$ structure was protected in the $\mathrm{P}_{2} \mathrm{~W}_{18} \mathrm{Ce}_{3} @ \mathrm{MIL}-101$ composite in the presence of hydrogen peroxide.

To investigate the applicability of this procedure, we carried out oxidation of different types of sulfides under the distinctive reaction conditions and the expected products afforded at high yields in $\mathrm{CH}_{3} \mathrm{CN}$ and $\mathrm{H}_{2} \mathrm{O}$ solvents for $\mathrm{P}_{2} \mathrm{~W}_{18} \mathrm{Sn}_{3} @ \mathrm{MIL}$ 101 (Table 2) and for $\mathrm{P}_{2} \mathrm{~W}_{18} \mathrm{Ce}_{3} @ M I L-101$ in EtOH (Table 3). As a result from this study, all used sulfides were oxidized to the corresponding sulfone and also noteworthy that $\mathrm{P}_{2} \mathrm{~W}_{18^{-}}$ $\mathrm{Ce}_{3} @ M I L-101$ composite shows better catalytic activity. In other word, substrates have high selectively to oxidation of sulfur singly even with the presence of functional groups such as aromatic and aliphatic sulfides. For example, 2-methylthio ethanol contains the hydroxyl group was transformed to the corresponding sulfone compound in high conversion and selectivity without dehydrogenation of the hydroxyl group.

\subsection{Stability of the catalysts}

In our final experimental work, stability tests (recovery and reusability) of the new $\mathrm{P}_{2} \mathrm{~W}_{18} \mathrm{Sn}_{3}$ @MIL-101 and $\mathrm{P}_{2} \mathrm{~W}_{18} \mathrm{Ce}_{3}$ @MIL-101 catalysts were carried out running six consecutive experiments in the oxidation of diphenyl sulfide at a constant time.

At the end of each reaction, the catalyst was recovered by simple centrifuge and was washed with ethyl acetate and ethanol $(4 \times 3 \mathrm{~mL})$, dried under vacuum then used again as the catalyst. The results show the reactions were completed in run of 1-5 at average time of $210 \mathrm{~min}$ (in $\mathrm{H}_{2} \mathrm{O}$ ) and $60 \mathrm{~min}$ (in EtOH) for $\mathrm{P}_{2} \mathrm{~W}_{18} \mathrm{Sn}_{3} @ M I L-101$ and $\mathrm{P}_{2} \mathrm{~W}_{18} \mathrm{Ce}_{3} @$ MIL-101, respectively. At the same reaction times the $6^{\text {th }}$ runs were completed up to 80 and $90 \%$ with $\mathrm{P}_{2} \mathrm{~W}_{18} \mathrm{Sn}_{3} @ \mathrm{MIL}-101$ and $\mathrm{P}_{2} \mathrm{~W}_{18} \mathrm{Ce}_{3} @ \mathrm{MIL}-101$ respectively (Fig. 7).

To investigate the structural stability of catalyst after oxidative reactions, IR spectra fresh and reused nanocomposites were recorded after six catalytic cycles (Fig. 8). The IR spectra of fresh catalyst are identical to those of reused catalyst, confirming the integrity of the support material and also the presence of the sandwich polyoxotungstate anions in the composite material after the catalytic performance.

\section{Conclusions}

Organic-inorganic frameworks based on different sandwichtype polyoxometalates using commercially and readily available materials were synthesized and their catalytic activities studied in the oxidation of different sulfides with an environmentally benign oxidant in different solvents. The nanocomposites have been achieved by impregnation of the synthesized MIL-101 in aqueous solution of the sandwich-type polyoxometalates. This is important point that by increasing concentration of polyoxometalates in aqueous solution, their loading into cages of MIL-101 is not significantly altered. Even 
after these relatively large anions signing into the MIL-101, there is still enough space to enter the reactants and get out of the product. The POMs insertion into porous MIL-101 solid was investigated using several methods: XRPD, FT-IR, SEMEDX, ICP, TGA and $\mathrm{N}_{2}$ adsorption. Catalysts have a useful life and as a result, with time, their activities and their effect on the reaction are reduced. This means that there are active points on the catalyst, which change over time due to different reasons. So today, the ability to recover and recycle catalyst from the environment is very important and significant. In synthesized composites, these active sites include polyoxometalates that are stable in the reaction media and do not suffer from it. The proposed mechanism for sulfides oxidation over polyoxometalates involves formation of peroxo-tungstate species (an electrophilic intermediate) by the interaction of hydrogen peroxide with the polyoxometalate anions which this transformation can oxidize the sulfides into sulfones. Therefore, in composites containing polyoxometalates, these are mainly catalytically active species that act as a catalyst. The best results were obtained by organic-inorganic framework incorporating of $\left[\left(\mathrm{HOSn}^{\mathrm{IV}} \mathrm{OH}\right)_{3}\left(\mathrm{PW}_{9} \mathrm{O}_{34}\right)_{2}\right]^{12-}$ and $\left[\left(\mathrm{OCe}^{\mathrm{IV}} \mathrm{O}\right)_{3}\left(\mathrm{PW}_{9} \mathrm{O}_{34}\right)_{2}\right]^{12-}$ among different sandwich polyoxometalates. The results of the BET and TGA analyses show that $\mathrm{P}_{2} \mathrm{~W}_{18} \mathrm{Sn}_{3} @ \mathrm{MIL}-101$ and $\mathrm{P}_{2}$ $\mathrm{W}_{18} \mathrm{Ce}_{3} @ M I L-101$ catalysts have lower specific surface area than MIL-101, while they show significant higher thermal stability. The advantages of this catalytic synthesis method it can be pointed out to low cost and availability of raw materials, easy synthesis and chemical and thermal stability.

\section{Conflicts of interest}

The authors declare that they have no competing interests.

\section{Acknowledgements}

The authors would like to thank the University of Kurdistan Research Council for their support of this work.

\section{References}

1 S. Zhao, Y. Chen and Y.-F. Song, Appl. Catal., A, 2014, 475, 140-146.

2 K. Mijares, Novel hybrid materials: Functionalized polyoxometalates as potential metalloligands, Kansas State University, Germany, 2008.

3 A. Proust, B. Matt, R. Villanneau, G. Guillemot, P. Gouzerh and G. Izzet, Chem. Soc. Rev., 2012, 41, 7605-7622.

4 C. L. Marchenaa, S. Gomeza, C. Sauxa, L. B. Pierellaa and L. R. Pizziob, Quim. Nova, 2015, 38, 518-525.

5 R. Ghanbaripour, I. Mohammadpoor-Baltork, M. Moghadam, A. R. Khosropour, S. Tangestaninejad and V. Mirkhani, Polyhedron, 2012, 31, 721-728.

6 X. Zheng, L. Zhang, J. Li, S. Luo and J.-P. Cheng, Chem. Commun., 2011, 47, 12325-12327.

7 Y. Guo, C. Hu, C. Jiang, Y. Yang, S. Jiang, X. Li and E. Wang, J. Catal., 2003, 217, 141-151.
8 R. Villanneau, A. Marzouk, Y. Wang, A. B. Djamaa, G. Laugel, A. Proust and F. Launay, Inorg. Chem., 2013, 52, 2958-2965.

9 X. Duan, Y. Liu, Q. Zhao, X. Wang and S. Li, RSC Adv., 2013, 3, 13748-13755.

10 M. Kooti and M. Afshari, Mater. Res. Bull., 2012, 47, 34733478.

11 M. Afshari, M. Gorjizadeh and G. Afshar, Orient. J. Chem., 2014, 29, 1675-1681.

12 R. Tan, C. Liu, N. Feng, J. Xiao, W. Zheng, A. Zheng and D. Yin, Microporous Mesoporous Mater., 2012, 158, 77-87.

13 E. Rafiee and S. Eavani, Green Chem., 2011, 13, 2116-2122.

14 M. Rahimizadeh, G. Rajabzadeh, S.-M. Khatami, H. Eshghi and A. Shiri, J. Mol. Catal. A: Chem., 2010, 323, 59-64.

15 J. Han, D. Wang, Y. Du, S. Xi, Z. Chen, S. Yin, T. Zhou and R. Xu, Appl. Catal., A, 2016, 521, 83-89.

$16 \mathrm{~S}$. Kaskel, The chemistry of metal-organic frameworks: synthesis, characterization, and applications, John Wiley \& Sons, Germany, 2016.

17 V. V. e. Butova, M. A. Soldatov, A. A. Guda, K. A. Lomachenko and C. Lamberti, Russ. Chem. Rev., 2016, 85, 280.

18 C.-D. Wu, A. Hu, L. Zhang and W. Lin, J. Am. Chem. Soc., 2005, 127, 8940-8941.

19 S. Lim, K. Suh, Y. Kim, M. Yoon, H. Park, D. N. Dybtsev and K. Kim, Chem. Commun., 2012, 48, 7447-7449.

20 S. Abednatanzi, A. Abbasi and M. Masteri-Farahani, J. Mol. Catal. A: Chem., 2015, 399, 10-17.

21 K. M. Taylor-Pashow, J. D. Rocca, Z. Xie, S. Tran and W. Lin, J. Am. Chem. Soc., 2009, 131, 14261-14263.

22 Y.-F. Huang, M. Liu, Y.-Q. Wang, Y. Li, J.-M. Zhang and S.-H. Huo, RSC Adv., 2016, 6, 15362-15369.

23 D. Y. Hong, Y. K. Hwang, C. Serre, G. Ferey and J. S. Chang, Adv. Funct. Mater., 2009, 19, 1537-1552.

24 S. H. Jhung, J. H. Lee, J. W. Yoon, C. Serre, G. Férey and J. S. Chang, Adv. Mater., 2007, 19, 121-124.

25 S. Biswas, S. Couck, M. Grzywa, J. F. Denayer, D. Volkmer and P. Van Der Voort, Eur. J. Inorg. Chem., 2012, 2012, 2481-2486.

26 G. Férey, C. Mellot-Draznieks, C. Serre, F. Millange, J. Dutour, S. Surblé and I. Margiolaki, Science, 2005, 309, 2040-2042.

27 L. Bromberg and T. A. Hatton, ACS Appl. Mater. Interfaces, 2011, 3, 4756-4764.

28 L. Bromberg, Y. Diao, H. Wu, S. A. Speakman and T. A. Hatton, Chem. Mater., 2012, 24, 1664-1675.

29 A. K. Babahydari, R. Fareghi-Alamdari, S. M. Hafshejani, H. A. Rudbari and M. R. Farsani, J. Iran. Chem. Soc., 2016, 13, 1463-1470.

30 D. Julião, A. C. Gomes, M. Pillinger, L. Cunha-Silva, B. de Castro, I. S. Gonçalves and S. S. Balula, Fuel Process. Technol., 2015, 131, 78-86.

31 H. Haddadi, S. M. Hafshejani and M. R. Farsani, Catal. Lett., 2015, 145, 1984-1990.

32 L. Bahrami, R. Khoshnavazi and A. Rostami, J. Coord. Chem., 2015, 68, 4143-4158.

33 F. Xin and M. T. Pope, J. Am. Chem. Soc., 1996, 118, 77317736. 
34 W. Knoth, P. Domaille and R. Harlow, Inorg. Chem., 1986, 25, 1577-1584.

35 S. Ribeiro, C. M. Granadeiro, P. Silva, F. A. A. Paz, F. F. de Biani, L. Cunha-Silva and S. S. Balula, Catal. Sci. Technol., 2013, 3, 2404-2414.

36 W. Salomon, F.-J. Yazigi, C. Roch-Marchal, P. Mialane, P. Horcajada, C. Serre, M. Haouas, F. Taulelle and A. Dolbecq, Dalton Trans., 2014, 43, 12698-12705.

37 A. Ghiasi Moaser and R. Khoshnavazi, New J. Chem., 2017, 41, 9472-9481.

38 F. Farzaneh and Y. Sadeghi, J. Mol. Catal. A: Chem., 2015, 398, 275-281.

39 Q. Liu, L. Ning, S. Zheng, M. Tao, Y. Shi and Y. He, Sci. Rep., 2013, 3, 2916-2921.

40 L. E. Briand, H. J. Thomas and G. T. Baronetti, Appl. Catal., A, 2000, 201, 191-202.

41 S. Abednatanzi, K. Leus, P. G. Derakhshandeh, F. Nahra, K. De Keukeleere, K. Van Hecke, I. Van Driessche, A. Abbasi, S. P. Nolan and P. V. Der Voort, Catal. Sci. Technol., 2017, 7, 1478-1487.

42 J. E. Mondloch, O. Karagiaridi, O. K. Farha and J. T. Hupp, CrystEngComm, 2013, 15, 9258-9264.

$43 \mathrm{X} . \mathrm{Hu}, \mathrm{Y} . \mathrm{Lu}, \mathrm{F} . \mathrm{Dai}, \mathrm{C}$. Liu and Y. Liu, Microporous Mesoporous Mater., 2013, 170, 36-44.

44 G. Leofanti, M. Padovan, G. Tozzola and B. Venturelli, Catal. Today, 1998, 41, 207-219.

45 N. D. Martínez, R. B. Venturini, H. S. Silva, J. E. González and A. M. Rodríguez, Mater. Res., 2009, 12, 45-50.
46 Y. Zhang, J. Wan, Y. Wang and Y. Ma, RSC Adv., 2015, 5, 97589-97597.

47 O. Lebedev, F. Millange, C. Serre, G. Van Tendeloo and G. Férey, Chem. Mater., 2005, 17, 6525-6527.

48 D. A. Islam, A. Chakraborty and H. Acharya, New J. Chem., 2016, 40, 6745-6751.

49 C. Saux, C. L. Marchena, L. R. Pizzio and L. B. Pierella, J. Porous Mater., 2016, 23, 947-956.

50 T.-H. Chen, K. W. Kwong, N. F. Lee, D. Ranburger and R. Zhang, Inorg. Chim. Acta, 2016, 451, 65-72.

51 H. Haddadi and M. R. Farsani, J. Cluster Sci., 2016, 27, 373386.

52 M. Dabiri, M. Koohshari, F. Shafipour, M. Kasmaei, P. Salari and D. MaGee, J. Iran. Chem. Soc., 2016, 13, 1265-1272.

53 I. C. Santos, J. A. Gamelas, T. A. Duarte, M. M. Simões, M. G. P. Neves, J. A. Cavaleiro and A. M. Cavaleiro, J. Mol. Catal. A: Chem., 2017, 426, 593-599.

54 W. Zhao and C. Yang, New J. Chem., 2013, 37, 1867-1870.

55 X. Xue, W. Zhao, B. Ma and Y. Ding, Catal. Commun., 2012, 29, 73-76.

56 H. Veisi, F. H. Eshbala, S. Hemmati and M. Baghayeri, RSC Adv., 2015, 5, 10152-10158.

57 Y. Jin, N. Li, H. Liu, X. Hua, Q. Zhang, M. Chen and F. Teng, Dalton Trans., 2014, 43, 12860-12870.

58 L. Zou, Q. Wang, Z. Wang, L. Jin, R. Liu and X. Shen, Ind. Eng. Chem. Res., 2013, 53, 658-663. 